Citation: Pocock NS, Mahmood SS, Zimmerman C, Orcutt, M. Imminent health crises among the Rohingya people of Myanmar. BMJ 2017;359:j5210. doi:10.1136/bmj.j5210 Available at: http://www.bmj.com/content/359/bmj.j5210

\title{
Imminent health crises among the Rohingya people of Myanmar
}

The international community must act to stop "slow burning genocide"

Nicola S. Pocock* (United Nations University International Institute of Global Health), Syed S. Mahmood* (NewYork Presbyterian Hospital-Weill Cornell Medical Centre), Cathy Zimmerman (London School of Hygiene and Tropical Medicine), Miriam Orcutt (University College London)

Corresponding author: nicola.pocock@unu.edu

The Rohingya people have resided in Myanmar since before 1799, ${ }^{12}$ but in 1982 the state stripped them of citizenship under the pretext that they were "illegal" migrants from Bangladesh. ${ }^{3}$ Decades of statelessness and systematic persecution of has meant the Rohingya have been excluded from education and healthcare, subjected to restrictions on births and marriages, and forced to relocate to camps for internally displaced persons, where their movement is severely restricted. As a consequence, the Rohingya people have an acute malnutrition rate 50\% higher than non-Rohingya residents in Rakhine state, and diarrheal illness rate five-fold greater than the general Myanmar population. ${ }^{2}$

\section{"Ethnic cleansing"}

Cycles of abuse against the Rohingya are seemingly relentless. Reports of sexual violence among women and children are pervasive. Since August 2017, Myanmar's military justified another wave of ruthless attacks as a response to violence by the Arakan Rohingya Salvation Army. Consequently, over 600000 Rohingya — or half of the 1.23 million Rohingya population of Myanmar-have fled to Bangladesh (Figure). ${ }^{24}$ A estimated $60 \%$ of new arrivals are children. For perspective, during the first six weeks of the Myanmar military assault the Rohingya fled in numbers that surpassed the total number of migrants and refugees arriving in Europe through the Mediterranean Sea during the whole of 2016. 
The ongoing military onslaught has destroyed more than 300 Rohingya villages, including more than 10000 homes. ${ }^{5}$ These offensives have included the use of helicopter gunships against civilians ${ }^{6}$ and widespread rape. ${ }^{7}$ The Office of the United Nations High Commissioner for Human Rights (OHCHR) has identified these abuses as crimes against humanity, ${ }^{2}$ and Myanmar's government has been accused of carrying out "ethnic cleansing." 8

${ }^{9}$ This term was coined by the late Yugoslav and Serbian politician Slobodan Milosevic for forced displacement and genocide, but is not included in international law-releasing the international community from its obligation to respond. ${ }^{10}$

\section{Responsibility to act}

Regardless of the legal debate, in the face of what the OHCHR suspects may be crimes against humanity and accounts of abuses tantamount to a slow burning genocide, ${ }^{11}$ the global health community has a responsibility to act.

Firstly, the international community must rapidly increase aid delivery for Rohingya arrivals and current camp residents in Bangladesh. Amid lack of shelter, food shortages, and inadequate healthcare, poor sanitation and shortages of potable water are contributing to severe dehydration and diarrhoea. In 1978 an estimated 10000 Rohingya, 7,000 of whom were children, died from starvation and diarrhoeal illness over several months. ${ }^{12}$ To avoid history repeating itself, sufficient resources must be allocated to implement preventive water, sanitation, and hygiene (WASH) and nutrition interventions, including the building of latrines, safe water storage in camps, distribution of ready-to-use food, and micronutrient supplements.

Secondly, Rohingya must be safeguarded from harm, especially while in flight. In particular, unaccompanied minors fleeing Myanmar must be protected from sexual violence, including sexual exploitation, forced child marriage, and recruitment as military sex slaves. Survivors will require safe shelter, clinical care, and mental health support. Health professionals along with humanitarian agencies in Indonesia, Malaysia, and Thailand must advocate for the safe reception of Rohingya arriving by boat. Agencies and health professionals must be prepared to provide immediate clinical and other support for new arrivals. All must protest anti-refugee responses, such as the potentially fatal naval actions in 2015 that pushed Rohingya back out to sea-which were ultimately stopped after an international outcry. 
Thirdly, as Bangladesh and Myanmar consider details of a verification process to return refugees, the Rohingya's safety, health, and wellbeing must be prioritised, particularly in light of their potential return to camps for internally displaced persons in Myanmar, where food and other supplies are dwindling. There are few places to which Rohingya can return. Many of their villages have been burned and reclaimed by the state. Health professionals must closely monitor any repatriation and advocate for the Rohingya's group identity to be recognised during documentation processes. Repatriation should be conditional on the guarantee of their physical safety and access to food systems, ensured by the presence of international peacekeepers. ${ }^{13}$

Fourth, data collection and information-sharing must be organised between international aid agencies, especially health providers, so that the full range of abuses can be documented and care needs can be understood and met. Data-driven evidence is essential for current advocacy, for future potential criminal prosecution, and as an accurate historical record.

The ongoing abuses of the Rohingya have resulted in as many living stateless and in dire conditions in camps within Bangladesh as there are left in Myanmar. These men, women and many, many children — and the more than 300000 Rohingya living across south east and south Asia - must receive urgent health prevention measures to protect them from what will surely be pending epidemics resulting from their exodus during this slow burning genocide.

Provenance: Not commissioned, not peer reviewed.

Competing interests: We have read and understood BMJ's policy on declaration of interests and declare the following: none.

*NP and SM contributed equally to the first draft of this manuscript. All authors contributed to compiling and critically revising this manuscript 
Figure: Exodus of Rohingya from Myanmar to Bangladesh (September 2 to November 11, 2017) [4]

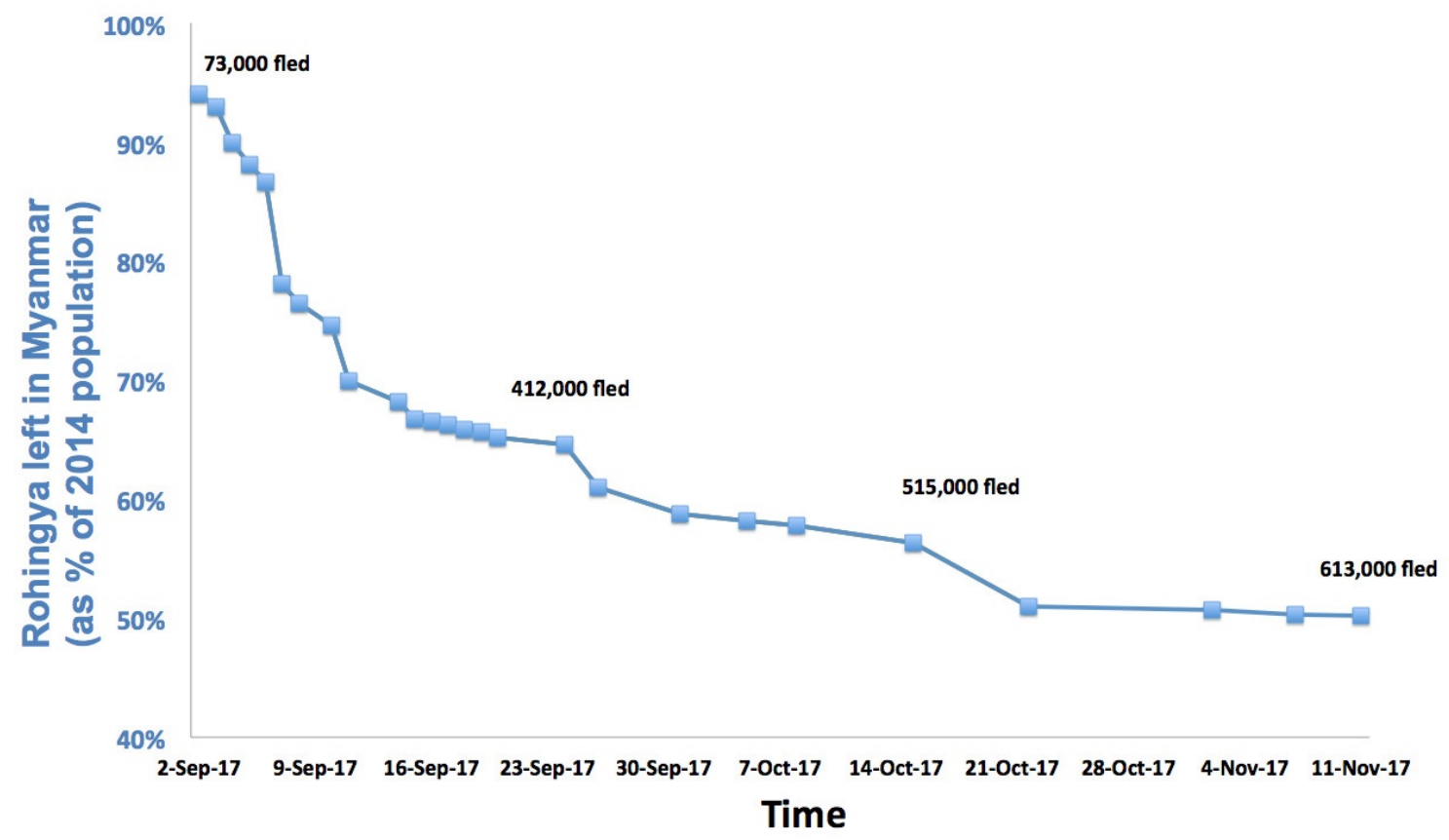

${ }^{1}$ Buchanan F. A comparative vocabulary of some of the languages spoke in the Burma Empire. Asiatic Researches; or, Transactions of the Society Instituted in Bengal for Inquiring into the History and Antiquities, the Arts, Sciences, and Literature of Asia. Calcutta: J Sewell; Vernor and Hood; J. Cuthell; J. Walker; R. Lea; Lackington, Allen and Co.; Ptridge and Son; R. Faulder; and J. Scatcherd; 1799: 219-40.

${ }^{2}$ Mahmood SS, Wroe E, Fuller A, Leaning J. The Rohingya people of Myanmar: health, human rights, and identity. Lancet 2017;389(10081):1841-50.

${ }^{3}$ Myanmar. Census. Population and Housing Census of Myanmar, 2014 (Vol I). In:

Population Do, editor. Nay Pyi Taw, Myanmar: Government of Myanmar; 2014. URL: data.unhcr.org/thailand/download.php?id $=421$

${ }^{4}$ Situation Report: Cox's Bazar Influx: Inter Sector Coordination Group, 2017. URL: https://www.humanitarianresponse.info/en/operations/bangladesh

${ }^{5}$ Burma: Satellite Imagery Shows Mass Destruction (Sep 19. 2017): Human Rights Watch, 2017. URL: https://www.hrw.org/news/2017/09/19/burma-satellite-imagery-shows-massdestruction

${ }^{6}$ Panzeri PA, Boştinaru V, Fleckenstein K, et al. European Parliament resolution on the situation of the Rohingya minority in Myanmar (2016/3027(RSP)). Brussels, Belgium:

European Parliament; 2016. p. 7. URL:

http://www.europarl.europa.eu/sides/getDoc.do?pubRef=-//EP//NONSGML+MOTION+B82016-1363+0+DOC+PDF+V0//EN

${ }^{7}$ Durbin R, McCain J, Feinstein D, Booker C, Menendez R, Leahy P. Senate Resolution 250. Washington, DC: United States of America Congress; 2017. p. 5. URL:

https://www.congress.gov/bill/115th-congress/senate-resolution/250/text?format=txt

${ }^{8}$ Center UN. UN human rights chief points to 'textbook example of ethnic cleansing' in Myanmar. United Nations News Center; 2017. URL:

http://www.un.org/apps/news/story.asp?NewsID=57490\#.Wc8ksYZrx0I 


\footnotetext{
${ }^{9}$ Beyrer C, Kamarulzaman A. Ethnic cleansing in Myanmar: the Rohingya crisis and human rights. Lancet 2017.

${ }^{10}$ Permanent People's Tribunal. Judgment from session on state crimes allegedly committed in Myanmar against the Rohingyas, Kachins, and other groups. University of Malaya, Faculty of Law 18-22 September 2017. https://tribunalonmyanmar.org/2017/10/31/ judgment-of-thepeoples-tribunal-on-myanmar.

${ }^{11}$ Zarni M, Cowley A. The Slow-Burning Genocide of Myanmar's Rohingya. Pacific Rim Law \& Policy Journal 23, 3 (2014): 683-754. Accessed 13 Nov 2017.

URL: http://digital.law.washington.edu/dspace-law/handle/1773.1/1377.

${ }^{12}$ Aall C. Disasterous international relief failure: A report on Burmese refugees in Bangladesh from May to December 1978. Disasters 1979; 3(4): 429-34. URL:

http://onlinelibrary.wiley.com/doi/10.1111/j.1467-7717.1979.tb00181.x/full

${ }^{13}$ Zarni M. The key issues to consider regarding Myanmar's official proposal for Rohingya repatriation. 2 Oct 2017. www.maungzarni.net/2017/10/the-key-issues-to-considerregarding.html.
}

Published by the BMJ Publishing Group Limited. All rights reserved. 